\title{
ANALISIS DATA FLIGHT OPERATION QUALITY ASSURANCE (FOQA) GARUDA INDONESIA BERBASIS WEB DI PT. GMF AEROASIA TBK
}

\author{
Rohmat Taufiq ${ }^{1}$, Angga Pradipta ${ }^{2}$, Ri Sabti Septarini ${ }^{3}$, Andhika Aratida Priadi ${ }^{4}$ \\ 1,2,3 Program Studi Teknnik Informatika, Fakultas Teknik, Universitas Muhammadiyah Tangerang Jalan Perintis \\ Kemerdekaan 1/33 Cikokol Kota Tangerang \\ Co Responden Email: rohmat.taufiq@umt.ac.id
}

\author{
Article history \\ Received Sept 22, 2020 \\ Revised Nov 15, 2020 \\ Accepted Feb 1, 2021 \\ Available online Februari 25 , \\ 2021 \\ Keywords \\ analysis, \\ reporting, \\ download \\ er, Flight \\ Data \\ System, \\ FDS
}

\section{Riwayat}

Diterima 22 Sept 2020

Revisi 15 Nov 2020

Disetujui 1 Feb 2021

Terbit 25 Februari

2021

Kata Kunci

analisis,

pelaporan,

downloader,

flight datas

system,

FDS

\begin{abstract}
The Flight Operation Quality Assurance (FOQA) download reporting data processing system on the Flight Data System (FDS) unit is by filling out an online form which is still in the form of a google form, this reporting is carried out by the downloader officer. This reporting is done in 3 stages, the first is writing the download form paper, then filling out the online form. Then the uploaded data will be analyzed by engineers and checked by the manager. Therefore, alternatives must be sought in handling this data. Based on this background, the problem being analyzed is that the manager has to see the downloader officer three times, so the best solution is how to create a web application to process download reporting data, so that performance in the Flight Data System (FDS) unit is more effective. The method used in writing this report is the waterfall method. So that reporting to superiors is more effective, detailed, easy, fast and accurate.
\end{abstract}

\begin{abstract}
Abstrak
Sistem pengolahan data pelaporan download Flight Operation Quality Assurance (FOQA) pada unit Flight Data System (FDS) yaitu dengan cara mengisi mengisi form online yang masih dalam bentuk google form, pelaporan ini dilakukan oleh petugas downloader. Pelaporan ini dilakukan dengan 3 tahap, yang pertama menulis dikertas download form, kemudian mengisi form online. Kemudian data yang diupload akan di analisa oleh engineer dan di check oleh manager. Oleh sebab itu harus di cari alternatif dalam penanganan data tersebut. Berdasarkan latar belakang tersebut, masalah yang di analisa adalah manager harus melihat tiga kali laporan petugas downloader, sehingga solusi terbaik adalah bagaimana cara membuat sebuah aplikasi web untuk mengolah data pelaporan download, supaya kinerja di unit Flight Data System (FDS) lebih efektif. Metode yang di lakukan dalam penulisan laporan ini adalah metode waterfall. Sehingga pelaporan kepada atasan lebih efektif terperinci, mudah cepat dan akurat.
\end{abstract}




\section{PENDAHULUAN}

Seiring dengan perkembangan teknologi yang semakin pesat, kebutuhan informasi sangat dibutuhkan terlebih informasi yang dihasilkan mengandung nilai yang benar, akurat, cepat dan tepat sehingga siapapun yang akan menggunakan infomasi tersebut dapat menangani masalah yang terjadi dengan cepat. Termasuk di dalam dunia penerbangan hampir semua aspek membutuhkan teknologi informasi.

Salah satu kegiatan pengelolaan data penerbangan pada PT. GMF AeroAsia khususnya di unit Flight Data System (FDS) yaitu pengambilan data penerbangan pesawat, untuk dibaca, dianalisa dan dikirim ke otoritas penerbangan Indonesia sebagai salah satu syarat perpanjangan ijin kelaikan udara, serta untuk memonitor langsung kondisi pesawat Garuda Indonesia oleh pihak PT.GMF AeroAsia.

Saat ini proses pelaporan hasil download masih dilakukan dengan cara menggunakan form manual dan diteruskan dengan menginput google form, sehingga data yang dilaporkan terpisah dengan pendataan atau pencatatan laporan perbulannya, serta proses pembuatan laporan yang belum tertata dengan baik. Sistem pelaporan yang masih manual tersebut menyebabkan belum optimalnya dalam pencarian data yang akan dianalisis.. jika data-data tersebut diperlukan dikemudian hari dan juga untuk keperluan dokumentasi file engineer.

Dengan demikian perlu diterapkan sistem yang terkomputerisasi pada Kantor PT. GMF AeroAsia, yang digunakan untuk membantu proses penginputan, pendataan dan pelaporan data. Berdasarkan dari latar belakang di atas, maka penulis tertarik untuk merancang sebuah sistem, dengan judul "Analisis Data Flight Operation Quality Assurance (FOQA) Garuda Indonesia Berbasis Web Pada PT. GMF AeroAsia Tbk".

\section{TINJAUAN PUSTAKA}

Analisis sistem adalah suatu cara atau teknik untuk menguraikan masalah dan mencari gambaran dari sistem yang ada atau sedang berjalan dan untuk mengetahui kelemahankelemahan dari sistem yang berjalan (Siagian, 2016). Sedangkan menurut Muharto dan Ambarita (2016) adalah "Kegiatan untuk menguraikan sub- sub sistem dan melihat fungsi dari masing-masing sub-sistem tersebut. Suryadi (2016) suatu sistem yang utuh ke dalam bagian-bagian komponennya dengan maksud untuk mengidentifikasi dan mengevaluasi permasalahan atau hambatan yang terjadi dari kebutuhan yang diharapkan sehingga dapat diusulkan perbaikan-perbaikannya.

Dalam tahapan analisis sistem terdapat langkah-langkah dasar yang harus dilakukan oleh seorang analis sistem, langkah tersebut terdiri dari Identify, Understand, Analysis dan Report (Husda dan Wangdra, 2016). Sistem informasi adalah kumpulan dari sub-sub sistem yang saling terintegrasi dan berkolaborasi untuk menyelesaikan masalah tertentu dengan cara mengolah data sehingga memiliki nilai tambah dan bermanfaat bagi pengguna (Taufiq, 2018).

Sistem informasi berbasis web memiliki banyak manfaat diantaranya memudahkan guru dan wali kelas maupun kepala sekolah untuk me review laporan pengolahan nilai selain itu juga dapat melihat pengolahan nilai secara online (Pertiwi dan Taufiq, 2020). Dengan berbasis web yang ada di smart phone para touris memanfaatkan untuk merencanakan dan memilih tujuan wisata serta menemukan perilaku wisatawan selama dalam perjalanan (Rusdi dkk, 2019). Dalam bidang pendukung keputusan bisa memberikan pemecahan masalah yang komplek, mempercepat proses pengambilan keputusan dan memberikan dukungan keputusan secara profesional (Taufiq dan Sugiharto, 2011).

Menurut Sembiring (2013) Flight Operation Quality Assurance singkatan dari FOQA adalah metode untuk menangkap, menganalisis, atau memvisualisasikan data yang dihasilkan oleh pesawat yang bergerak di udara dari satu titik ke titik lainnya. Manfaat menerapkan FOQA diantaranya sebagai berikut: identifikasi peristiwa tidak aman, melakukan analisis tren masalah keamanan, benchmark operasi dengan database global dan lain-lain (FDAS, 2021). Direktorat Jenderal Penerbangan Sipil (DGCA) telah mewajibkan semua operator maskapai untuk melakukan Analisis Data Penerbangan untuk keselamatan penerbangan. Instruksi dengan jelas menyatakan perlunya departemen keselamatan 
penerbangan untuk semua operator yang dijadwalkan. Operator yang tidak terjadwal diharuskan untuk menyajikan laporan keselamatan secara setengah tahunan kepada DGCA. (Dirjen Perhubungan Udara, 2020)

\section{METODE PENELITIAN}

Dalam metode penelitian ini yang dilakukan terdapat 6 langkah yang terdiri dari komunikasi, rencana, pengumpulan data, analisis, desan dan pembuatan laporan.

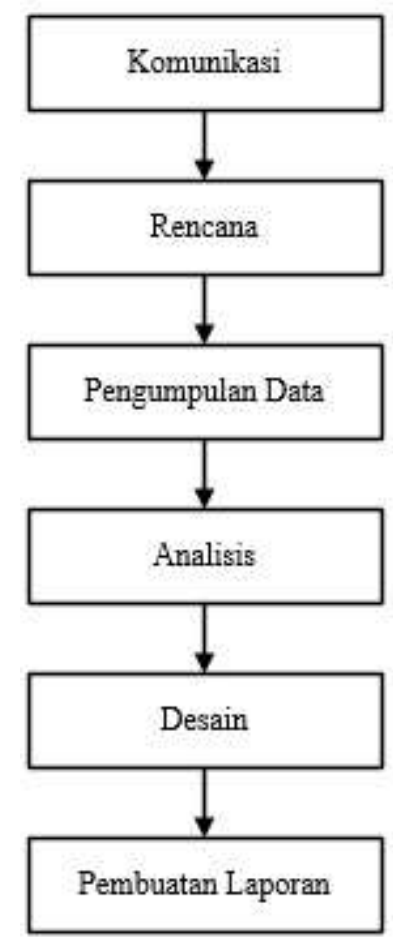

Gambar 1 Metode Penelitian

Komunikasi merupakan langkah awal dalam penelitian ini, yang dilakukkan dalam komunikasi untuk mengetahui sistem yang berjalan di perusahaan. Langkah selanjutnya yaitu rencana, yang dilakukan membuat perencanaan bagaimana cara menganalisis dan mendesain, alat apa yang dibutuhkan dan berapa lama waktu yang akan dipergunakan.

Langkah ketiga yaitu pengumpulan data, yang dilakukan dengan cara wawancara, observasi dan literatur. Langkah keempat yaitu analisis, yang dilakukan dalam analisis yaitu mengetahui bagaimana proses yang berjalan dari sistem. Langkah kelima yaitu desain, yang dilakukan membuat desain logic dengan menggunakan
Unified Modelling Language (UML) dan desain fisik dengan menggambar tampilan form yang diusulkan. Selain pembuatan UML dalam langkah ini juga melakukan proses perancangan sistem sampai dengan pengujian.

Langkah yang terakhir yaitu membuat laporan akhir yang bisa dijadikan sebagai acuan untuk mempelajari proses dari sistem atau dari laporan tersebut bisa digunakan untuk proses pengembangan dalam waktu yang akan datang.

\section{HASIL DAN PEMBAHASAN \\ Sistem yang Berjalan}

Penulis melakukan analisa dan perancangan sistem data FOQA (Flight Operation Quality Assurance) Garuda Indonesia pada PT GMF Aeroasia Tbk, selama 3 bulan terhitung dari bulan juni sampai bulan agustus 2020. Selama penelitian itu menyimpulkan bawa sistemyang berjalan sebagaimana digambarkan dalam flowhart dibawah ini.

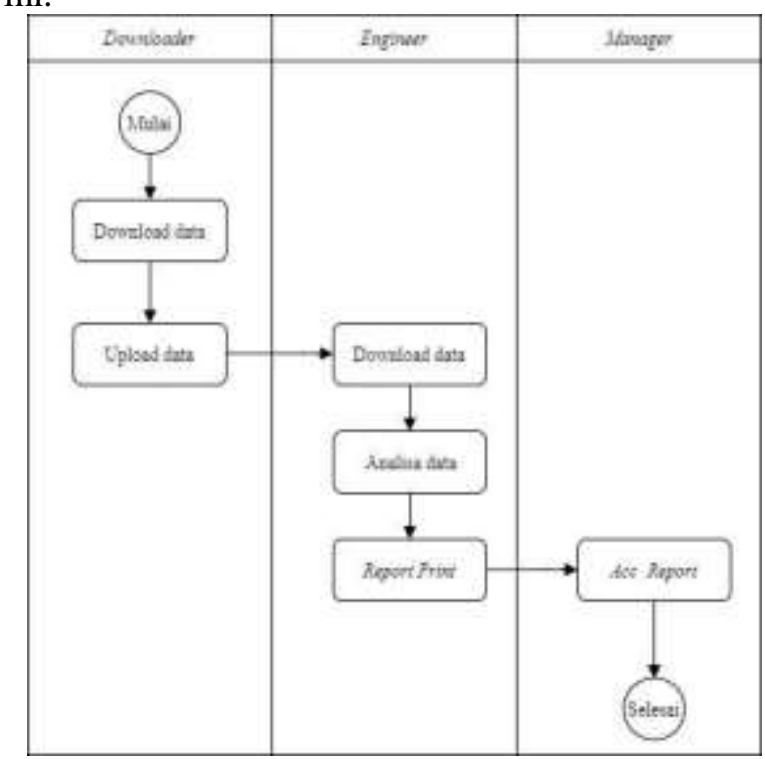

Gambar 2 Flowchart sistem yang berjalan

PT. GMF Aeroasia yang di dalamnya terdapat unit Flight Data Management dalam mengelola data penerbangan setiap pesawat dimulai dengan mendownload data kemudian data tersebut di olah sebagaimana keperluannya, seperti untuk melengkapi dokumen test kelaikan udara, dan untuk case jika ada pesawat yang hardlanding sebagai bahan investigasi aircraft crew untuk mengetahui tingkat kerusakan pada pesawat supaya bisa diperbaiki oleh yang bersangkutan. 


\section{Use Case}

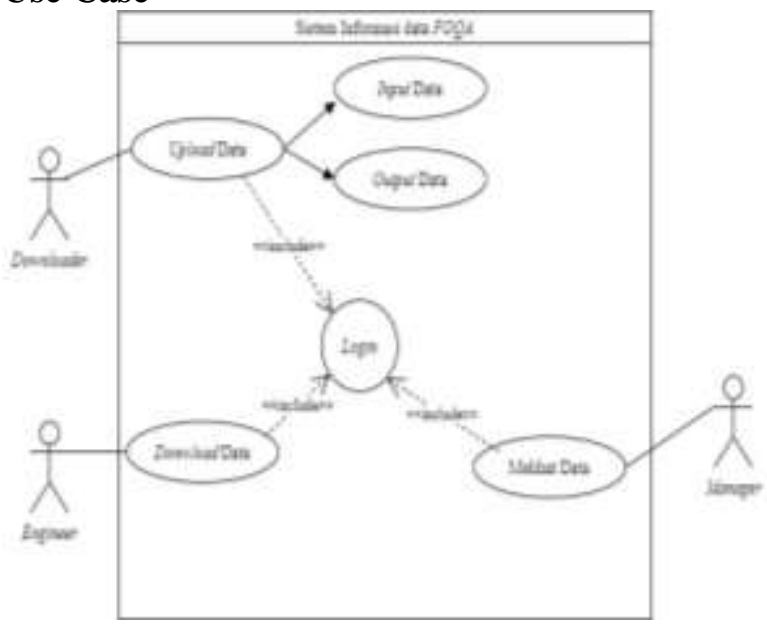

Gambar 3 Use Case

Dalam use case tersebut terdapat 3 aktor yang terdiri dari Manager, Downloader dan Engineer. Masing-masing aktor memiliki hak akses,tugas dan fungsi sendiri-sendiri.

\section{Statechart diagram}

Terdapat 4 statechart diagram yaitu login, input data, output data dan download data. Namun dalam paper ini hanya menampilkan statechart diagram input data.

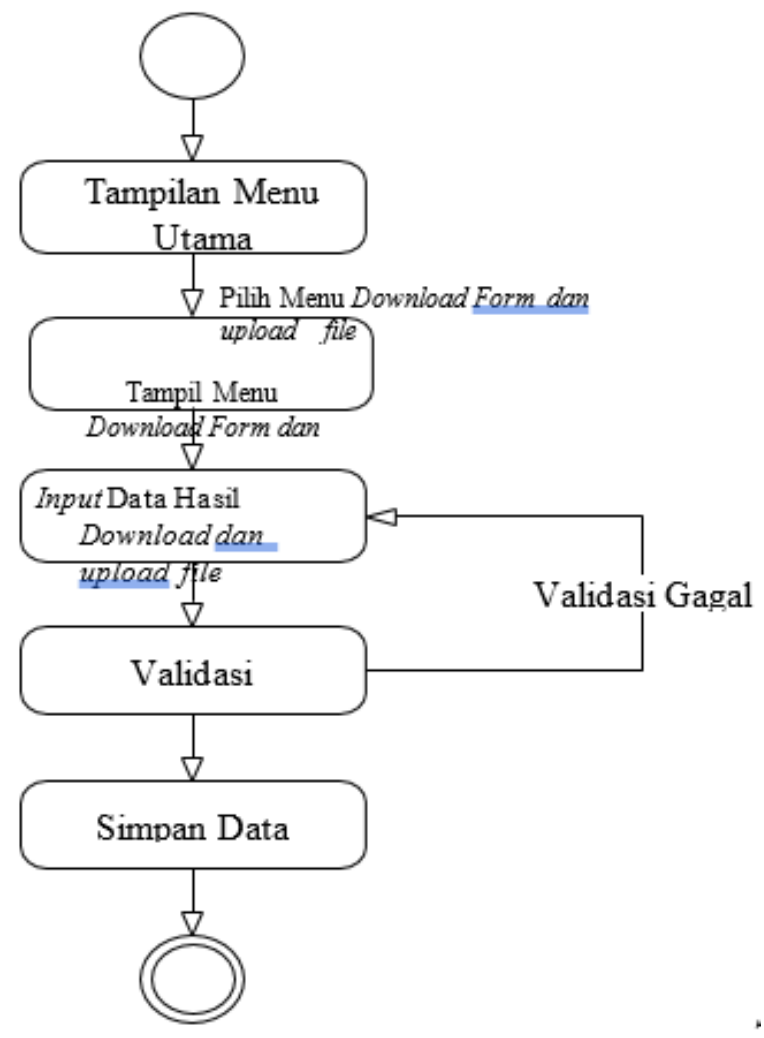

Gambar 4 Statechart diagram input data

Gambar 4 statechart diagram menunjukkan bagaimana seorang aktor downloader melakukan input data.

\section{Activity Diagram}

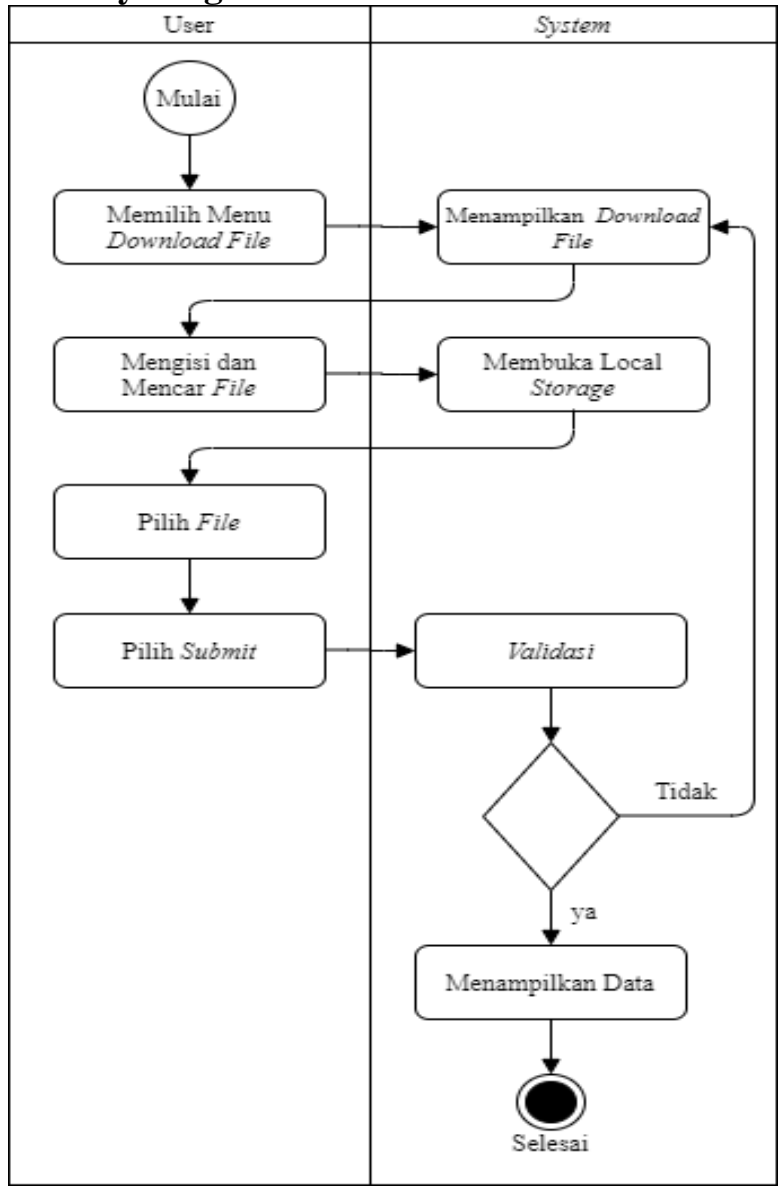

Gambar 5 Activity Diagram download Data

Dalam gambar 5 diatas menjelaskan bagaimana seorang aktor melakukan download file.

\section{Form Login}

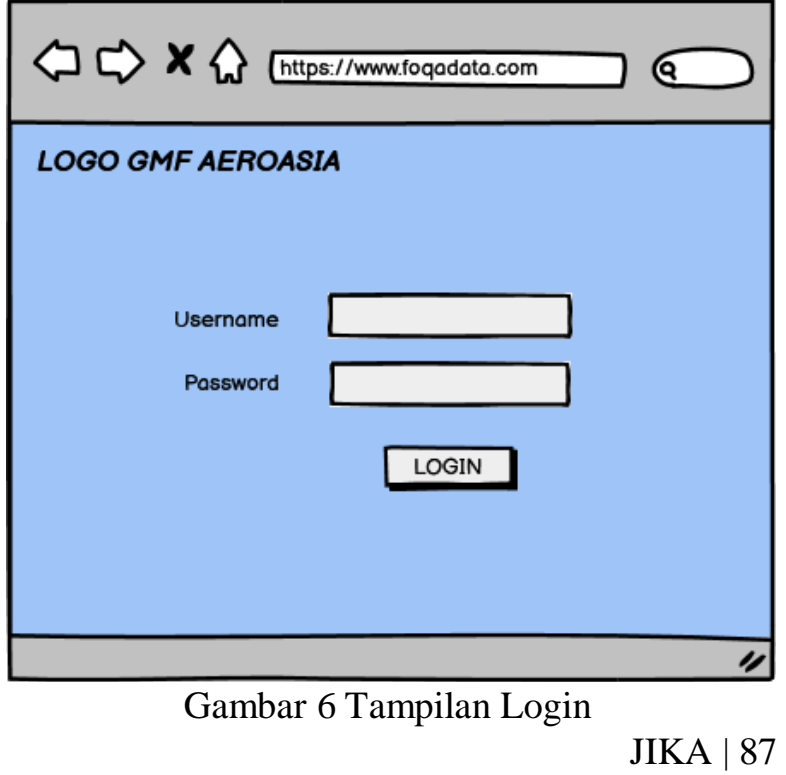


Dalam gambar 6 tersebut ada 3 user yang diberikan hak akses yang terdiri dari manager, downloader dan engineer. Masing-masing aktor memilik tugas dan fungsi yang berbeda-beda.

\section{Menu Utama}

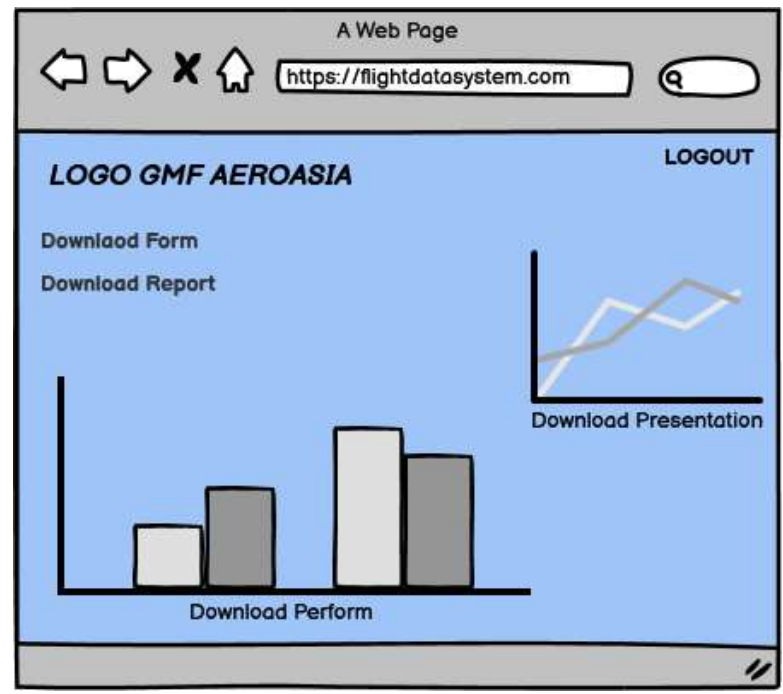

Gambar 7 Menu Utama

Dalam menu utama yang ada dalam desain analisis data FOAQ dijelaskan dengan gambar 7 diatas. Gambar diatas menjelaskan bahwa pada saat aplikasi dibuat maka akan memiliki kemampuan untuk mendownload form dan melakukan download laporan.

\section{Form Download}

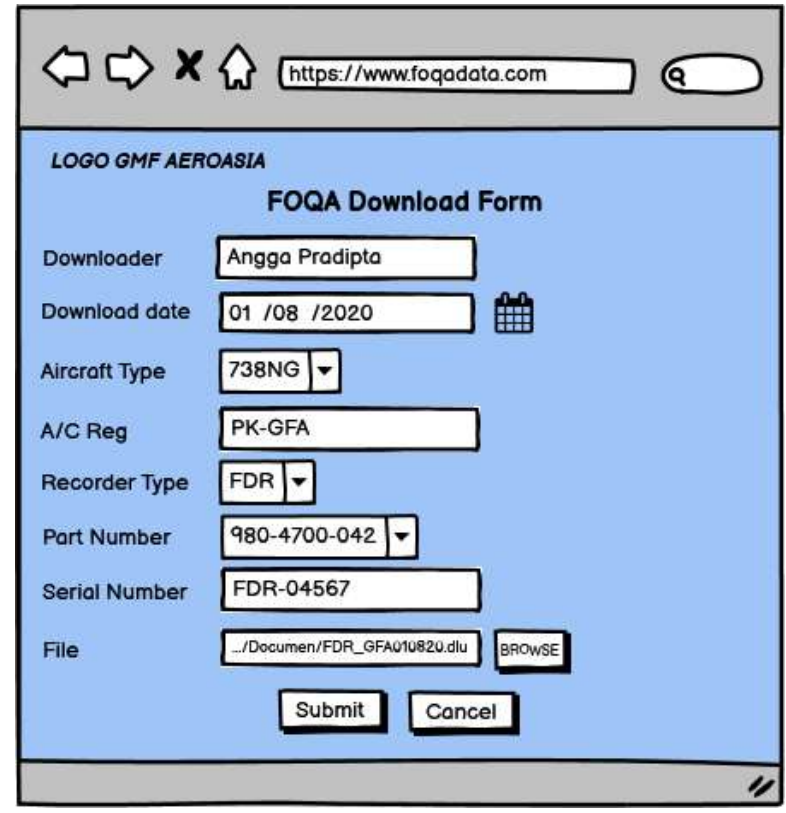

Gambar 8 Form Download

Gambar 8 diatas menggambarkan tampilan dari FOQA download form. Dimana form tersebut memiliki kemampuan untuk melakukan pencarian melalui tombol brows. Lalu akan muncul field Nama Downloader, Data yang Didownload, Type, A/C Reg, Recorder Type, Port Number, Serial Number dan File.

\section{Form Download Report}

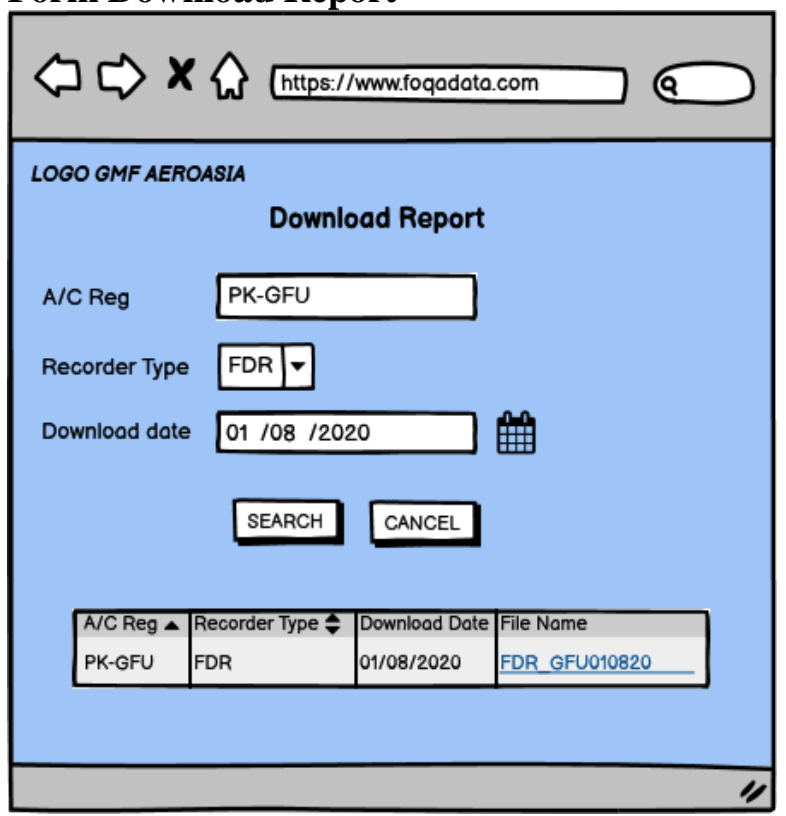

Gambar 9 Form Download Report

Gambar diatas berfungsi untuk mendownload laporan. Laporan yang dihasilkan berupa file pdf. Dalam form tersebut juga bisa digunakan untuk menampilkan A/C Reg, Recorder Type, Download data. Sedangkan aplikasinya sendiri juga mampu digunakan untuk melakukan pencarian.

\section{KESIMPULAN}

Berdasarkan uraian dari proses analisa dan perancangan maka dapat disimpulkan sebagai berikut:

1. Dalam proses analisa data Flight Operation Quality assurance (FOQA) pada PT GMF AeroAsia Tbk masih di bantu dengan Ms. Office dan dengan dokumen-dokumen yang menggunakan media kertas, sehingga sering terjadi kendala kehilangan identitas data.

2. Sistem yang ada masih belum efektif karena belum terdapat sebuah aplikasi yang memiliki server dan database tersendiri.

3. Desain sudah dibuat dan sudah sesuai dengan harapan pengguna. 


\section{REFERENSI}

Direktorat Jenderal Perhubungan Udara. 2002. Profil Dirjen edisi September 2020. Link http://hubud.dephub.go.id akses 8 Februari 2021.

Elfi, NH dan Yvonne,W (2016). Pengantar Teknologi Informasi. Jakarta. Baduose Media.

Flight Data Analysis Services (FDAS) (2012). Link https://www.13harris.com/allcapabilities/flight-data-analysis-services. Diakses 8 Februari 2021.

Muharto, Ambarita Arisandy (2016). Metode Penelitian Sistem Informasi. Yogyakarta: Deepublish.

Pertiwi, D.D and Taufiq, R. 2020. "Analisis dan Desain Sistem Informasi Pengolahan Nilai Siswa di SMK Avicena Rajeg", J. Tek. Inform. Univ. Muhammadiyah Tangerang. ISSN: 2549-0710.

PRIYANGGODO, Dyas Yudi. Pemanfaatan GPS Sebagai Sarana Mendapatkan Pertolongan Ketika dalam Kondisi Bahaya dengan Algoritma Divide and Conquer untuk Menentukan Lokasi Terdekat. JIKA (Jurnal Informatika), 2019, 3.1.

Rusdi, J. F., Salam, S., Abu, N. A., Sunaryo, B., Taufiq, R., Muchlis, L. S., ... Vitianingsih, A. V. (2019). Dataset Smartphone Usage of International Tourist Behavior. Data in Brief, 104610. https://doi.org/10.1016/j.dib.2019. $\underline{104610 .}$.

Sembiring., Javensius, Holzapfel., Florian, Extracting of Unmeasured Parameters Based on Quick Access Recorder Data Using Parameter Estimation Method, AIAA Atmospheric Flight Mechanics Conference, Boston, USA, Agustus 2013.

Siagian, Saut (2016). Analisis dan Perancangan Sistem Informasi Rekam Medik Pada
Puskesmas Pakuan Baru. Scientia Journal Vol. 5 No. 2. Desember 2016. Pp. 118-125. Suryadi, Emi. 2016. "Sistem Pendukung Keputusan Pemilihan Kendaraan Dalam Mendistribusikan Zakat, Infak dan Sedekah". Yogyakarta: STMIK AMIKOM Yogyakarta. Jurnal CCIT. Vol. 9 No. 3, Agustus 2016.

Taufiq, R. (2018) "Pengantar Sistem Informasi". Jakarta. Mitra Wacana Media. 